Jurnal Ekonomi Balance Fakultas Ekonomi Dan Bisnis

Volume 11 No 1 Tahun 2015

\title{
PENGARUH BUDAYA ORGANISASI DAN KOMITMEN ORGANISASIONAL TERHADAP KINERJA KARYAWAN PT. PELINDO IV (PERSERO) CABANG MAKASSAR
}

\author{
Samsul Rizal ${ }^{1}$ ASHAR MAESYAR ${ }^{2}$ Arfan Jalil $^{3}$ \\ Program Studi Manajemen Fakultas Ekonomi Dan Bisnis \\ Universitas Muhammadiyah Makassar \\ (asharmaesyar@gmail.com)
}

\begin{abstract}
ABSTRAK
Penelitian ini bertujuan untuk menganalisis pengaruh budaya organisasi dan komitmen organisasional terhadap kinerja karyawan. Penelitian ini menggunakan data primer yang diperoleh dengan menyebar kuesioner kepada karyawan yang bekerja di PT. Pelindo IV (Persero) Cab. Makassar. Metode analisis data yang digunakan dalam penelitian ini meliputi uji validitas dan uji reliabilitas, serta uji hipotesis dengan menggunakan analisis regresi liniear berganda. Hasil penelitian menunjukan dalam uji $\mathrm{F}$ (simultan) bahwa budaya organisasi dan komitmen organisasi secara signifikan mempengaruhi kinerja karyawan dengan nilai sig $\mathrm{F}$ $0,000<0,05$. Hasil uji t (parsial) menunjukan budaya organisasi secara signifikan mempengaruhi kinerja karyawan dengan nilai sig t 0,002 <0,05, dan komitmen organisasional secara signifikan mempengaruhi kinerja karyawan dengan nilai sig t 0,000 < 0,05. Jadi, dapat disimpulkan bahwa budaya organisasi dan komitmen organisasional mempengaruhi kinerja karyawan baik secara simultan maupun parsial.
\end{abstract}

Kata Kunci: Budaya Organisasi, Komitmen Organisasional, dan Kinerja Karyawan.

\section{PENDAHULUAN}

\section{Latar Belakang}

Setiap organisasi akan selalu meningkatkan kualitas sumber dayanya agar kinerjanya memuaskan. Peningkatan kualitas tersebut juga merupakan salah satu upaya untuk menjadikan karyawan lebih termotivasi dan jelas arah tujuan yang ingin dicapai. Masalah tentang kinerja karyawan merupakan masalah yang perlu diperhatikan organisasi, karena kinerja karyawan akan mempengaruhi kualitas dan kuantitas organisasi dalam menghadapi persaingan seiring perkembangan zaman. Karena itu, memiliki sumber daya manusia (karyawan) yang berkualitas sangat dibutuhkan agar tujuan organisasi dapat tercapai dan dapat meningkatkan kinerja karyawan dalam suatu organisasi.

Apabila sumber daya manusianya memiliki motivasi tinggi, kreatif dan mampu mengembangkan inovasi, kinerjanya akan menjadi semakin baik. Namun, kinerja yang baik tidak akan dihasilkan tanpa adanya budaya organisasi 
Jurnal Ekonomi Balance Fakultas Ekonomi Dan Bisnis

Volume 11 No 1 Tahun 2015

dan komitmen organisasional yang mendukung berjalannya organisasi itu sendiri. Budaya organisasi inilah yang kemudian mempengaruhi kinerja karyawan dalam mencapai tujuan organisasi serta menimbulkan kesadaran dan keinginan pada karyawan untuk memiliki komitmen pada organisasi sehingga akan tercipta loyalitas dan produktivitas kerja yang maksimal dalam mencapai tujuan baik individu maupun organisasi.

Robbins (2010:76) menjelaskan bahwa budaya organisasi telah diketengahkan sebagai nilai-nilai, prinsip-prinsip, tradisi dan cara-cara bekerja yang dianut bersama oleh para anggota organisasi dan mempengaruhi cara mereka bertindak. Pada hakikatnya semua organisasi memiliki budaya, namun tidak semua budaya organisasi sama kuatnya dalam mempengaruhi perilaku dan tindakan para karyawan. Semakin tinggi tingkat penerimaan para karyawan terhadap nilai-nilai pokok organisasi dan semakin besar komitmen mereka pada nilai-nilai tersebut, semakin kuat budaya organisasinya. Akan tetapi, budaya kuat juga memiliki kelemahan yaitu budaya organisasi yang kuat cenderung menghambat para karyawan untuk berani mencoba cara-cara baru, terutama dalam menghadapi situasi yang berubah cepat.

Dalam hal ini jelaslah bahwa budaya yang tertanam dalam organisasi memiliki kontribusi yang signifikan terhadap kinerja karyawan. ketika karyawan memahami nilai-nilai yang ada dalam organisasinya, maka akan mempengaruhi bagaimana kinerjanya. Pratiwi (2012:70) dalam penelitiannya menjelaskan bahwa budaya organisasi mempunyai pengaruh yang signifikan terhadap kinerja karyawan. Besarnya budaya organisasi berpengaruh $32 \%$ terhadap kinerja karyawan sedang $68 \%$ dipengaruhi oleh variabel lain. Hal ini berarti bahwa apabila budaya organisasi mengalami peningkatan, maka akan meningkatkan kinerja karyawan pula dan begitu pun sebaliknya, apabila budaya organisasi mengalami penurunan, maka kinerja karyawan pun akan mengalami penurunan.

Karyawan yang memiliki komitmen organisasi yang tinggi akan memberikan usaha yang maksimal secara sukarela untuk kemajuan organisasi. Mereka akan berusaha mencapai tujuan organisasi dan menjaga nilai-nilai organisasi. Selain itu, mereka akan berpartisipasi dan terlibat aktif untuk memajukan organisasi. Karyawan yang memiliki komitmen yang tinggi akan bertanggung jawab dengan bersedia memberikan seluruh kemampuannya karena merasa memiliki organisasi. 
Jurnal Ekonomi Balance Fakultas Ekonomi Dan Bisnis

Volume 11 No 1 Tahun 2015

Sitty Yuwalliantin (2006) dalam penelitiannya menerangkan bahwa Komitmen terhadap organisasi artinya lebih dari sekedar keanggotaan formal, karena meliputi sikap menyukai organisasi dan kesediaan untuk mengusahakan tingkat upaya yang tinggi bagi kepentingan organisasi demi pencapaian tujuan. Jadi seseorang yang memiliki komitmen tinggi akan memiliki identifikasi dengan organisasi, terlibat sungguh-sungguh dalam pekerjaan dan ada loyalitas serta afeksi positif terhadap organisasi. Dimana komitmen organisasi memberi pengaruh positif dan signifikan terhadap kinerja.

Perkembangan dalam dunia usaha di Indonesia saat ini yang semakin cepat dan pesat berakibat juga pada perubahan budaya. Sehingga organisasi dituntut untuk mempunyai budaya yang membedakan dengan organisasi lain yang sejenis. Kesuksesan sebuah organisasi juga tidak hanya didukung oleh budaya organisasi saja tetapi juga bagaimana organisasi tersebut menumbuhkan komitmen karyawan. Tuntutan karyawan yang semakin tinggi terhadap organisasi serta apa yang dilakukan organisasi akan menentukan bagaimana komitmen atau keterikatan karyawan terhadap organisasi, yang pada akhirnya mempengaruhi keputusannya untuk tetap tergabung dan memajukan organisasinya atau memilih tempat kerja lain yang lebih menjanjikan.

Kinerja menjadi sesuatu yang menarik diperbincangkan pada perusahaan PT. Pelabuhan Indonesia IV (Persero) cabang Makassar. atau biasa disingkat PT. Pelindo IV. Perusahaan ini adalah salah satu perusahanaan milik negara yang memberi kontribusi besar terhadap pendapatan negara Indonesia. Sehingga bisa dikatakan dengan kondisi tersebut perusahaan ini otomatis memiliki jumlah karyawan yang tidak sedikit mengingat di beberapa kawasan besar Indonesia Pelindo dibagi berdasarkan wilayah regionalnya. Dalam penelitian ini difokuskan khusus pada wilayah regional IV yang ada di Kota Makassar tentang bagaimana kinerja karyawan dalam perusahaan ini.

Budaya organisasi sudah tercipta pada saat berdirinya PT. Pelindo IV (Persero) Cab. Makassar. Budaya organisasi pada PT. Pelindo IV (Persero) Cab. Makassar, menerapkan nilai-nilai saling menghormati antar karyawan, bertanggung jawab terhadap pekerjaan masing-masing, karyawan harus mempunyai kreativitas dan inovasi dalam bekerja, budaya tersebut turut mendorong berkembangnya perusahaan hingga saat ini. Tingkat masuk keluar (turnover) karyawan di PT. Pelindo IV (Persero) Cab. Makassar mengalami fluktuasi hampir setiap tahun. Keluarnya karyawan akan merugikan kinerja 
Jurnal Ekonomi Balance Fakultas Ekonomi Dan Bisnis

Volume 11 No 1 Tahun 2015

perusahaan jika tidak ada upaya dari perusahaan untuk menurunkan tingkat masuk-keluar (turnover) karyawan.

Budaya kerja yang tertanam dalam PT. Pelindo IV (Persero) Cab. Makassar menjadikan titik utama gerak organisasi sehingga diharapkan karyawan mampu menjadi loyal dan berkomitmen terhadap PT. Pelindo IV sebagai perusahaan milik negara sehingga masyarakat dan pemerintah tetap mempercayakan pelayanan transportasi laut ini. Sebagai perusahaan yang bergerak dibidang transportasi agar selalu mengedepankan karyawannya untuk bisa bekerja secara professional. Karyawan bekerja sesuai dengan tugasnya masing-masing, karena dikhawatirkan karyawan akan "kabur-kaburan" dengan pekerjaan yang cukup berat, karena adanya tekanan baik eksternal maupun internal dan kesediaan ditempatkan diwilayah mana saja, terlebih banyaknya godaan untuk melakukan tindakan KKN dan perilaku menyimpang lainnya dalam orgnisasi mengingat perusahaan ini memiliki banyak sumber dana dari pemerintah dan juga penghasilan yang tidak sedikit.

Budaya organisasi yang tumbuh dalam Pelindo semestinya dapat meningkatkan komitmen karyawannya sehingga dapat menghasilkan kinerja yang memuaskan. Namun bentuk komitmen yang muncul diharapkan bukan hanya bersifat loyalitas yang pasif, tetapi juga melibatkan hubungan yang aktif dengan organisasi kerja yang memiliki tujuan memberikan segala usaha demi keberhasilan organisasi, Karena mereka yang lebih berkomitmen terhadap organisasinya akan lebih siap melakukan berbagai upaya demi keberhasilan organisasi. Kolaborasi antara budaya organisasi dan komitmen diharapkan mampu menjadi kesatuan yang kokoh sehingga dapat menghasilkan kinerja yang baik dan sesuai dengan pencapaian tujuan.

Kualitas kerja, efisiensi, kemampuan karyawan, ketepatan waktu, pengetahuan karyawan, kreativitas, serta melaksanakan tugas sesuai prosedur pada PT. Pelindo IV (Persero) Cab. Makassar. Penilaian kinerja yang ada selama ini hanya dilakukan dengan berdasarkan absensi bagi karyawan. Sehingga untuk mencapai peningkatan kinerja yang diinginkan sesuai dengan indikator-indikator tersebut, dibutuhkan penelitian lebih lanjut. Berdasarkan latar belakang tersebut, maka diadakan penelitian dengan judul "Pengaruh Budaya Organisasi dan Komitmen Organisasional Terhadap Kinerja Karyawan PT. Pelabuhan Indonesia IV (Persero) Cabang Makassar". 
Jurnal Ekonomi Balance Fakultas Ekonomi Dan Bisnis

Volume 11 No 1 Tahun 2015

\section{METODE PENELITIAN}

Penelitian ini termasuk dalam ruang lingkup penelitian Manajemen Sumber Daya Manusia. Kemudian, dalam penelitian ini menggunakan data primer yang bersumber dari karyawan PT. Pelabuhan Indonesia IV (Persero), Cabang Makassar dan akan dijadikan bahan penelitian. Data tersebut diperoleh melalui kuesioner dan dokumentasi kepada karyawan perusahaan tersebut yang berkaitan dengan variabel-variabel yang akan diteliti. Adapun data yang diperoleh bertujuan untuk menganalisis ada atau tidaknya pengaruh serta manakah variabel yang dominan berpengaruh antara budaya organisasi (X1) dan komitmen organisasional (X2) terhadap kinerja karyawan (Y) PT. Pelindo IV (Persero) Cab. Makassar.

Penelitian ini berlokasi di Jl. Soekarno No.1 Makassar yang menjadi wilayah kantor PT. Pelabuhan Indonesia IV (Persero) Cabang Makassar. Waktu penelitian dilaksanakan berdasarkan lamanya penelitian yang dilakukan, yaitu mulai dari pengusulan judul penelitian, survey lapangan, penulisan proposal, pengumpulan dan pengolahan data, hingga perampungan hasil penelitian yang membutuhkan waktu sekitar 2 (dua) bulan.

Populasi adalah wilayah generalisasi yang terdiri atas: obyek/subyek yang mempunyai kualitas dan karakteristik tertentu yang ditetapkan oleh peneliti untuk dipelajari dan kemudian ditarik kesimpulannya (Sugiyono, 2009: 115). Dalam penelitian ini, populasinya adalah karyawan PT. Pelindo IV (Persero), Cabang Makassar yang berjumlah 147 orang. Sampel adalah bagian dari jumlah dan karakteristik yang dimiliki oleh populasi tersebut. Jika populasi besar dan peneliti tidak mungkin mempelajari semua yang ada pada populasi, misalnya karena keterbatasan dana, tenaga dan waktu, maka peneliti dapat menggunakan sampel yang diambil dari populasi itu (Sugiyono, 2009: 116).

Tehnik penentuan sampel yang digunakan adalah convenience sampling, yaitu unit sample yang digunakan mudah untuk dihubungi, tidak menyusahkan, mudah untuk mengukur dan bersifat kooperatif. Bila data yang dianalisa dengan statistik parametik, maka jumlah sampel harus besar, karena nilai-nilai atau skor yang diperoleh distribusinya harus mengikuti distribusi normal. Sampel yang tergolong sampel besar yang distribusinya normal adalah sampel yang jumlahnya $>30$ kasus. Bilamana analisa yang dipakai adalah teknik korelasi, 
Jurnal Ekonomi Balance Fakultas Ekonomi Dan Bisnis

Volume 11 No 1 Tahun 2015

maka sampel yang harus diambil minimal 30 kasus. (Singarimbun, 2006 : 171) Dalam penelitian ini, metode yang digunakan untuk menentukan sampel adalah rumus Slovin dalam Sugiyono (2009:81), yaitu sebagai berikut:

$$
\mathbf{n}=
$$

Dimana:

$\mathrm{n}=$ Jumlah sampel

$\mathrm{N}=$ Jumlah populasi

$\mathrm{e}=$ Batas kesalahan maximal yang ditolerir dalam sampel $(10 \%)$

$$
\begin{aligned}
\mathrm{n} & =\mathrm{N} \\
& =1+\mathrm{N}(\mathrm{e})^{2} \\
& =\quad 147 \\
& =\begin{aligned}
147 & =59,51 \\
3,15 & =5,10)^{2}
\end{aligned}
\end{aligned}
$$

Jadi, nilai $\mathrm{n}$ adalah 59,51 orang atau dibulatkan menjadi 60 orang.

Jenis data yang digunakan dalam penelitian ini terbagi menjadi dua, yaitu Data Kualitatif merupakan data yang diperoleh dari jawaban kuesioner yang disebarkan kepada sejumlah karyawan yaitu sebanyak 60 responden dan data Kuantitatif yaitu data yang diperoleh dalam bentuk angka yang dapat dihitung. Data ini diperoleh dari perhitungan kuisioner yang berhubungan dengan masalah yang dibahas dalam skripsi ini.

Sumber data yang dgunakan dalam penelitian ini terdiri dari dua macam yaitu Data Primer yang diperoleh dengan mengumpulkan langsung dari objek penelitian, yaitu menyebarkan secara langsung kuisioner kepada responden terpilih. Data Sekunder yang berupa informasi yang dapat diperoleh dari perusahaan, internet, majalah, koran, dan buku-buku yang berhubungan dengan penelitian ini.

Pengumpulan data sangatlah penting karena berkaitan dengan tersedianya data yang dibutuhkan untuk menjawab permasalahan dalam penelitian sehingga kesimpulan yang diambil adalah benar. Oleh karena itu, penelitian metode pengumpulan data harus dilakukan dengan cara yang tepat. Dalam penelitian ini pengumpulan data yang digunakan oleh peneliti adalah: 
Jurnal Ekonomi Balance Fakultas Ekonomi Dan Bisnis

Volume 11 No 1 Tahun 2015

a. Metode Angket (kuesioner)

Kuesioner adalah sejulah pertanyaan tertulis yang digunakan untuk memperoleh informasi dan responden dalam arti laporan tentang pribadinya atau hal-hal yang ia ketahui (Arikunto, 1998: 139). Metode ini dilakukan untuk pengambilan data tentang budaya organisasi dan komitmen organisasi serta pengaruhnya terhadap kinerja karyawan pada PT. Pelindo IV (Persero), Makassar. Kuesioner untuk mengukur budaya organisasi, komitmen Organisasi karyawan dan kinerja karyawan diberikan kepada karyawan itu sendiri. Untuk mengetahui distribusi frekuensi masing-masing variabel yang pengumpulan datanya menggunakan kuesioner (angket), setiap indikator dari data yang dikumpulkan terlebih dahulu diklasifikasikan dan diberi skor atau nilai.

b. Metode Dokumentasi

Metode dokumentasi adalah mencari data mengenai hal-hal atau variasi yang berupa catatan, transkrip, buku, surat kabar, majalah, prasasti notulen rapat, agenda dan sebagainya (Arikunto, 1998: 234). Metode ini digunakan sebagai pelengkap guna memperoleh data sebagai bahan informasi yang digunakan penelitian ini yang meliputi struktur organisasi.

c. Observasi

Tehnik ini dilakukan dengan cara mengamati langsung dalam proses kegiatan keseharian pegawai pada PT. Pelindo IV (Persero) Cabang Makassar. Instrumen merupakan hal yang sangat penting didalam kegiatan penelitian. Hal ini karena perolehan suatu informasi atau data relevan atau tidaknya, tergantung pada alat ukur tersebut. Oleh karena itu, alat ukur penelitian harus memiliki validitas dan realibilitas yang memadai. Menurut Sugiyono (2012 : 132), instrumen penelitian diirancang untuk satu tujuan penelitian dan tidak bisa digunakan pada penelitian yang lain. Susunan instrumen untuk setiap penelitian tidak selalu sama dengan penelitian yang lain. Hal ini disebabkan karena setiap penelitian mempunyai tujuan dan mekanisme kerja yang berbeeda-beda. Adapun skala pengukurannyadiukur dengan menggunakan metode skala likert (Likerts Summated Ratings), dengan bobot pengukuran, yaitu:

- Skor 1 jika jawaban responden sangat tidak setuju (STS)

- Skor 2 jika jawaban responden tidak setuju (TS)

- $\quad$ Skor 3 jika jawaban responden kurang setuju (KS)

- Skor 4 jika jawaban responden setuju (S)

- Skor 5 jika jawaban responden sangat setuju (SS) 
Jurnal Ekonomi Balance Fakultas Ekonomi Dan Bisnis

Volume 11 No 1 Tahun 2015

\section{Variabel Penelitian dan Defenisi Operasional}

Menurut Sugiono (2009:58) Variabel penelitian adalah segala sesuatu yang berbentuk apa saja yang ditetapkan oleh peneliti untuk dipelajari sehingga diperoleh informasi tentang hal tersebut, yang kemudian peneliti dapat menarik kesimpulannya.

\section{a. Variabel Independen (Variabel Bebas)}

Variabel ini sering disebut sebagai variabel stimulus, prediktor, antecedent. Dalam bahasa indonesia sering disebut sebagai variabel bebas. Variabel bebas adalah merupakan variabel yang mempengaruhi atau yang menjadi sebab perubahannya atau timbulnya variabel dependen (terikat). (Sugiono, 2009: 59). Dalam penelitian ini peneliti menjadikan budaya organisasi dan komitmen organisasi sebagai variabel bebas (variabel independen) yang dapat mempengaruhi variabel dependen yaitu kinerja karyawan. Dalam hal ini budaya organisasi dilambangkan dengan lambang X1 dan komitmen organisasional dengan lambang $\mathrm{X} 2$.

\section{b. Variabel Dependen (Variabel Terikat)}

Variabel ini sering disebut variabel output, kriteria, konsekuen. Dalam bahasa indonesia sering disebut sebagai variabel terikat. Variabel terikat merupakan variabel yang dipengaruhi atau yang menjadi akibat karena adanya variabel bebas. (Sugiono, 2009: 59). Dalam penelitian ini, peneliti menjadikan kinerja karyawan sebagai variabel terikat yang dipengaruhi oleh dua variabel bebas (budaya organisasi dan komitmen organnisasional). Untuk mempermudah penelitian, peneliti merumuskan kinerja karyawan dengan lambang $Y$ yang dipengaruhi X1 (budaya organisasi) dan X2 (komitmen organisasional).

\section{c. Definisi Operasional}

Definisi operasional adalah sesuatu yang melekat arti pada suatu variabel dengan cara menetapkan kegiatan atau tindakan yang perlu untuk mengukur variabel itu. Pengertian operasional variabel ini diuraikan melalui tabel dibawah ini. 
Jurnal Ekonomi Balance Fakultas Ekonomi Dan Bisnis

Volume 11 No 1 Tahun 2015

Tabel 3.2

Operasional Variabel Penelitian

\begin{tabular}{|c|c|c|c|c|}
\hline No & Variabel & Sub Variabel & Indikator & Ukuran \\
\hline 1. & $\begin{array}{l}\text { Budaya Organisasi }(\mathrm{X} 1) \\
\text { sistem nilai organisasi } \\
\text { yang dianut oleh anggota } \\
\text { organisasi itu sendiri, } \\
\text { yang kemudian } \\
\text { mempengaruhi cara } \\
\text { bekerja dan berperilaku } \\
\text { dari para anggota } \\
\text { organisasi. } \\
\text { (Denison, 1990) }\end{array}$ & $\begin{array}{l}\text { A. Keterlibatan } \\
\text { (involvement) } \\
\text { B. Konsistensi } \\
\text { (concistency) } \\
\text { C.Adaptabilitas } \\
\text { (adaptibility) } \\
\text { D. Misi } \\
\text { (mission) }\end{array}$ & $\begin{array}{l}\text { a. Empowerement } \\
\text { b. Team orientation } \\
\text { a. Agreement } \\
\text { b. Core values } \\
\text { a. Creating change } \\
\text { b. Customer focus } \\
\text { a. goals and } \\
\text { objectives } \\
\text { b. vission }\end{array}$ & Ordinal \\
\hline 2. & $\begin{array}{l}\text { Komitmen } \\
\text { Organisasional (X2) } \\
\text { suatu keadaan dimana } \\
\text { karyawan merasa terikat } \\
\text { oleh organisasi dan } \\
\text { ingin mempertahankan } \\
\text { keanggotaannya dalam } \\
\text { organisasi tersebut serta } \\
\text { mengabdikan diri untuk } \\
\text { kepentingan organisasi. } \\
\text { (Meyer dan Allen dalam } \\
\text { Luthans, 2008) }\end{array}$ & $\begin{array}{l}\text { A. Affective } \\
\text { Commitment } \\
\text { B. ontinuance } \\
\text { Commitment }\end{array}$ & $\begin{array}{l}\text { a. Karyawan memiliki } \\
\text { ikatan emosional } \\
\text { b. Karyawan merasa } \\
\text { rugi jika } \\
\text { meninggalkan } \\
\text { organisasi } \\
\text { c. Kesadaran } \\
\text { karyawan bahwa } \\
\text { komitmen } \\
\text { terhadap } \\
\text { organisasi } \\
\text { merupakan hal } \\
\text { yang memang } \\
\text { seharusnya } \\
\text { dilakukan }\end{array}$ & Ordinal \\
\hline 3. & $\begin{array}{l}\text { Kinerja }(\mathrm{Y}) \\
\text { Kemampuan seseorang } \\
\text { dalam mencapai hasil } \\
\text { kerja secara kualitas dan } \\
\text { kuantitas dalam } \\
\text { melaksanakan tugas } \\
\text { sesuai dengan } \\
\text { tanggungjawab yang } \\
\text { diberikan kepadanya. } \\
\text { (Wirawan, 2009) }\end{array}$ & $\begin{array}{l}\text { A. Hasil kerja } \\
\text { B. Perilaku } \\
\text { kerja } \\
\text { C. Sifat pribadi }\end{array}$ & $\begin{array}{l}\text { a. Kualitas kerja } \\
\text { b. Kuantitas kerja } \\
\text { a. Disiplin kerja } \\
\text { b.Inisiatif dalam } \\
\text { bekerja } \\
\text { c. kerja sama } \\
\text { a. kemampuan } \\
\text { beradaptasi } \\
\text { b. kesabaran } \\
\text { c. kejujuran dalam } \\
\text { bekerja }\end{array}$ & Ordinal \\
\hline
\end{tabular}


Jurnal Ekonomi Balance Fakultas Ekonomi Dan Bisnis

Volume 11 No 1 Tahun 2015

\section{Uji Validitas dan Uji Realibilitas}

\section{a. Uji Validitas}

Validitas adalah suatu ukuran yang menunjukan tingkatan-tingkatan kevalidan atau kesahihan suatu instrumen (Arikunto, 1998:60). Instrumen dikatakan valid jika mampu mengukur apa yang diinginkan, apabil dapat mengungkapkan data variabel yang diteliti secara tepat. Dalam penelitian ini validitas yang digunakan adalah dengan uji Pearson Correlation. Pengujian validitas data dapat diperoleh dengan cara mengkorelasikan skor yang diperoleh pada setiap item pertanyaan dengan skor total dari masing-masing konstruk. Apabila koefisien pearson yang diperoleh memiliki signifikansi di bawah level 0,05 berarti data yang diperoleh adalah valid.

\section{b. Uji Realibilitas}

Realibilitas menunjukan pada suatu instrumen cukup dapat dipercaya untuk digunakan sebagai alat pengumpul data karena instrumen tersebut sudah baik (Arikunto, 1998:170). Realibilitas merupakan ukuran suatu kestabilan dan konsistensi responden dalam menjawab hal yang berkaitan dengan konstrukkonstruk pertanyaan yang merupakan dimensi suatu variabel dan disusun dalam suatu bentuk kuesioner. Pengukuran realibilitas dapat dilakukan dengan dua cara yaitu:

1) Repeated Measure atau pengukuran ulang, Disini seseorang akan diberikan pertanyaan yang sama pada waktu yang berbeda, dan kemudian dilihat apakah ia tetap konsisten dengan jawabannya.

2) One Shot atau pengukuran sekali saja, pengukuran hanya dilakukan satu kali dan kemudian hasilnya dibandingkan dengan pertanyaan lain atau mengukur korelasi antar jawaban pertanyaan. SPSS memberikan fasilitas untuk mengukur reliabilitas dengan uji statistik Cronbach's Alpha (a). Suatu konstruk atau variabel dikatakan reliabel jika memberikan nilai Cronbeach Alpha> 0,60 (Ghozali, 2009:48).

\section{Metode Analisis}

Untuk menguji hipotesis yang sudah dirumuskan peneliti menggunakan analisis regresi linier berganda dan pengujian hipotesis.

\section{a. Analisis Regresi Berganda}

Analisis Regresi merupakan metode analisis yang tepat ketika penelitian melibatkan satu variabel terikat yang diperkirakan berhubungan dengan satu atau lebih variabel bebas, (Hair Anderson Tatham Black, 1995 dalam Sofyan 
Jurnal Ekonomi Balance Fakultas Ekonomi Dan Bisnis

Volume 11 No 1 Tahun 2015

Yamin dan Heri Kurniawan, 2009:81). Analisis regresi berganda, yaitu suatu analisis untuk melihat seberapa besar pengaruh variabel bebas terhadap variabel terikat. Berdasarkan uraian diatas penelitian ini bertujuan untuk mengetahui pengaruh variabel bebas yaitu Budaya Organisasi (X1), dan Komitmen Organisasional (X2) terhadap Kinerja Karyawan (Y). Adapun bentuk persamaan regresi linier berganda adalah sebagai berikut:

Keterangan:

$\begin{array}{cl}\text { Y } & \text { : Kinerja Karyawan } \\ \text { A } & : \text { Intercept (konstanta) } \\ \text { b1 } & \text { : Koefisien regresi untuk X1 } \\ \text { b2 } & \text { : Koefisien regresi untuk X2 } \\ \text { X1 } & \text { : Budaya Organisasi } \\ \text { X2 } & \text { : Komitmen Organisasional } \\ \text { E } & \text { : Nilai residu (tingkat kesalahan) }\end{array}$

Pengolahan hasil dari metode analisis penelitian ini menggunakan komputer dengan memanfaatkan program SPSS versi 20 yang dapat memberikan hasil yang cepat dan akurat. Hasil perhitungan dari model analisis tersebut dapat digunakan sebagai dasar dalam menganalisis untuk membuktikan hipotesis-hipotesis yang diajukan.

\section{Pengujian Hipotesis}

\section{1) Uji Koefisiensi Determinasi}

Koefisien determinasi $\left(R^{2}\right)$ pada intinya mengukur seberapa jauh kemampuan model dalam menerangkan variasi variabel dependen. Dalam output SPSS, koefisien determinasi terletak pada table model summery ${ }^{b}$ dan tertulis $R$ square. Namun untuk regresi linier berganda sebaliknya menggunakan $R$ square yang sudah disesuaikan atau tertulis adjusted $R$ square, karena disesuaikan dengan jumlah variabel independen yang digunakan dalam penelitian. Nilai $R^{2}$ yang semakin mendekati 1 , berarti variabel-variabel bebas memberikan hampir semua informasi yang dibutuhkan untuk memprediksi variasi variabel bebas. Sebaliknya jika $\mathrm{R}^{2}$ mendekati 0 (nol), maka semakin lemah pengaruh variabel bebas terhadap variabel terikat. (Gujarati, 2003 dalam Ghozali, 2011:97). 
Jurnal Ekonomi Balance Fakultas Ekonomi Dan Bisnis

Volume 11 No 1 Tahun 2015

\section{2) Uji Signifikansi Simultan (Uji Statistik F)}

Uji statistik $F$ digunakan untuk menunjukkan kesesuaian data dengan model yang digunakan untuk menentukan akurasi daya prediksi variabel independen terhadap variabel dependen. Pengujian dilakukan dengan membandingkan nilai $F_{\text {hitung }}$ dengan $F_{\text {tabel }}$ pada derajat kesalahan 5\% $(\alpha=0.05)$. Apabila nilai $F_{\text {hitung }} \geq$ dari nilai $F_{\text {tabel, }}$ maka berarti variabel bebasnya secara serempak memberikan pengaruh yang bermakna terhadap variabel terikat atau hipotesis pertama diterima.

\section{3) Uji Parsial ( Uji T )}

Kuncoro (2003:218) menjelaskan bahwa Uji t pada dasarnya menunjukkan seberapa jauh pengaruh satu variabel penjelas secara individual dalam menerangkan variasi variabel terikat. Kemudian, bila membandingkan nilai $t$ hitung dan nilai t tabel, jika hilai t hitung lebih tinggi dibanding nilai t tabel dengan tingkat signifikansi $(\alpha)=0.05$, itu berarti kita menerima hipotesis alternatif yang menyatakan bahwa suatu variabel independen secara individual mempengaruhi variabel dependen (Kuncoro, 2003:219). Uji ini dapat sekaligus digunakan untuk mengetahui seberapa besar pengaruh masing-masing variabel bebas tersebut yang mempengaruhi kinerja karyawan, dengan melihat nilai-nilai t masing-masing variabel. Berdasarakan nilai $t$, maka dapat diketahui variabel bebas mana yang dominan mempengaruhi variabel terikat. 
Jurnal Ekonomi Balance Fakultas Ekonomi Dan Bisnis

Volume 11 No 1 Tahun 2015

HASIL DAN PEMBAHASAN

\section{Uji Validitas dan Uji Reliabilitas}

\section{a. Uji Validitas}

Uji validitas dapat dikatakan valid apabila semua indikator dalam penelitian memiliki nilai total pearson correlation $>0,50$. Berdasarkan hal itu, dapat dilihat dari tabel berikut dengan menggunakan program SPSS 20. Hasil uji validitas data dapat dilihat pada Tabel 4.3.1 berikut ini.

Tabel 4.3.1 Hasil Uji Validitas

\begin{tabular}{|c|c|c|c|c|}
\hline Dimensi & Item & $\begin{array}{c}\text { Total Pearson } \\
\text { Correlation }\end{array}$ & $\mathbf{r}_{\text {standar }}$ & Keterangan \\
\hline \multirow{8}{*}{ Budaya Organisasi $(\mathrm{X} 1)$} & $\mathrm{X} 1.1$ & 0,512 & 0,50 & Valid \\
\hline & $\mathrm{X} 1.2$ & 0,534 & 0,50 & Valid \\
\hline & $\mathrm{X} 1.3$ & 0,807 & 0,50 & Valid \\
\hline & $\mathrm{X} 1.4$ & 0,808 & 0,50 & Valid \\
\hline & $\mathrm{X} 1.5$ & 0,847 & 0,50 & Valid \\
\hline & $\mathrm{X} 1.6$ & 0,765 & 0,50 & Valid \\
\hline & $\mathrm{X} 1.7$ & 0,547 & 0,50 & Valid \\
\hline & $\mathrm{X} 1.8$ & 0,671 & 0,50 & Valid \\
\hline \multirow{6}{*}{$\begin{array}{c}\text { Komitmen } \\
\text { Organisasional (X2) }\end{array}$} & $\mathrm{X} 2.1$ & 0,623 & 0,50 & Valid \\
\hline & $\mathrm{X} 2.2$ & 0,773 & 0,50 & Valid \\
\hline & $\mathrm{X} 2.3$ & 0,826 & 0,50 & Valid \\
\hline & $\mathrm{X} 2.4$ & 0,788 & 0,50 & Valid \\
\hline & X2.5 & 0,755 & 0,50 & Valid \\
\hline & $\mathrm{X} 2.6$ & 0,573 & 0,50 & Valid \\
\hline \multirow{8}{*}{ Kinerja $(Y)$} & Y.1 & 0,712 & 0,50 & Valid \\
\hline & Y.2 & 0,636 & 0,50 & Valid \\
\hline & Y.3 & 0,665 & 0,50 & Valid \\
\hline & Y.4 & 0,622 & 0,50 & Valid \\
\hline & Y.5 & 0,539 & 0,50 & Valid \\
\hline & Y.6 & 0,738 & 0,50 & Valid \\
\hline & Y.7 & 0,663 & 0,50 & Valid \\
\hline & Y.8 & 0,653 & 0,50 & Valid \\
\hline
\end{tabular}

Sumber : hasil olah data SPSS 20, 2015 
Jurnal Ekonomi Balance Fakultas Ekonomi Dan Bisnis

Volume 11 No 1 Tahun 2015

Dari tabel diatas, terlihat bahwa keseluruhan item pertanyaan memiliki nilai total pearson correlation di atas 0,50, sehingga dapat dikatakan bahwa butir instrumen tersebut sudah valid.

\section{b. Uji Reliabilitas}

Uji Reliabilitas digunakan untuk mengetahui konsistensi alat ukur, apakah alat ukur dapat diandalkan untuk digunakan lebih lanjut. Hasil uji reliabilitas dalam penelitian ini menggunakan koefisien cronbach's alpha, dimana menurut Ghozali (2009:133) bahwa instrumen dikatakan reliabel jika memiliki koefisien cronbach's alpha sama dengan 0,60 atau lebih. Hasil uji reliabilitas data dapat dilihat pada Tabel 4.3 .2 berikut ini :

Tabel 4.3.2

Hasil Uji Reliabilitas

\begin{tabular}{|c|l|c|c|}
\hline No. & \multicolumn{1}{|c|}{ Variabel Penelitian } & Cronbach's Alpha & Keterangan \\
\hline 1 & Budaya Organisasi (X1) & 0,807 & Reliabel \\
\hline 2 & Komitmen Organisasional (X2) & 0,814 & Reliabel \\
\hline 3 & Kinerja (Y) & 0,804 & Reliabel \\
\hline
\end{tabular}

Sumber : Hasil olah data SPSS 20, 2015

Berdasarkan tabel hasil uji reliabilitas diatas, dapat dilihat bahwa nilai Cronbach Alpha untuk masing-masing variabel $X_{1}(0,807), X_{2}(0,814)$, dan $Y$ $(0,804)$ lebih besar dari 0,6 . Hal ini menunjukkan bahwa indikator-indikator dalam penelitian ini dapat dikatakan reliable dengan menggunakan variabel independen budaya organisasi (X1) dan komitmen organisasional (X2), serta variabel dependen kinerja karyawan $(Y)$. Sehingga dapat disimpulkan bahwa semua itemitem pengukur variabel dari kuesioner reliabel yang berarti bahwa kuesioner yang digunakan dalam penelitian ini merupakan kuesioner yang handal.

\section{Analisis dan Pembahasan}

\section{a. Analisis Regresi Linear Berganda}

Analisis hasil penelitian mengenai variabel budaya organisasi dan komitmen organisasional yang dominan terhadap kinerja karyawan pada PT. Pelindo IV (Persero) Cab. Makassar, dianalisis menggunakan metode pengolahan data melalui persamaan regresi linear berganda dengan bantuan program SPSS 20. Pembuktian ini dimaksudkan untuk menguji variasi suatu model regresi yang digunakan dalam menerangkan variabel bebas $(X)$ terhadap variabel terikat $(Y)$ 
Jurnal Ekonomi Balance Fakultas Ekonomi Dan Bisnis

Volume 11 No 1 Tahun 2015

dengan cara menguji signifikansi dari koefisien regresinya. Hasil olahan data dengan menggunakan program SPSS 20 dapat dilihat pada tabel 4.4 .1 berikut ini:

Tabel 4.4.1

Hasil analisis regresi linear berganda

\begin{tabular}{|c|c|c|c|c|c|}
\hline \multirow[t]{2}{*}{ Model } & \multicolumn{2}{|c|}{$\begin{array}{l}\text { Unstandardized } \\
\text { Coefficients }\end{array}$} & $\begin{array}{c}\text { Standardize } \\
\text { d } \\
\text { Coefficients }\end{array}$ & \multirow[t]{2}{*}{$\mathrm{T}$} & \multirow[t]{2}{*}{ Sig. } \\
\hline & B & Std. Error & Beta & & \\
\hline $\begin{array}{l}\text { (Consta } \\
\text { nt) }\end{array}$ & 3,602 & 11,840 & & ,505 & ,615 \\
\hline $\mathrm{X} 1$ & 141 & ,082 & ,047 & 3,287 & ,002 \\
\hline $\mathrm{X} 2$ & ,831 & ,110 & ,707 & 7,547 & ,000 \\
\hline
\end{tabular}

a. Dependent Variabel : $Y$

Sumber : hasil olah data SPSS 20, 2015

Berdasarkan hasil olahan data regresi dengan menggunakan program komputerisasi SPSS versi 20, maka dapat dipaparkan dengan persamaan regresi sebagai berikut :

Dari hasil persamaan regresi tersebut di atas, maka akan disajikan penjelasan dari persamaan regresi yaitu: hasil konstanta $b_{0}$ sebesar 3,602 , dapat diartikan bahwa tanpa adanya pengaruh dari variabel bebas budaya organisasi $\left(X_{1}\right)$ dan komitmen organisasional $\left(X_{2}\right)$, persepsi karyawan terhadap kinerjanya berada pada nilai skala 3,602 (baik). Untuk variabel $b_{1}$ sebesar 0,141 , hal ini menunjukkan bahwa setiap peningkatan satu skala pada budaya organisasi akan menghasilkan peningkatan sebesar 0,141 pada persepsi karyawan terhadap kinerjanya.

Demikian pula untuk variabel $b_{2}$ sebesar 0,831 dapat diartikan bahwa setiap peningkatan satu skala pada komitmen organisasional akan menghasilkan peningkatan sebesar 0,831 pada persepsi karyawan terhadap kinerjanya. 
Jurnal Ekonomi Balance Fakultas Ekonomi Dan Bisnis

Volume 11 No 1 Tahun 2015

Berdasarkan hasil persamaan regresi tersebut, menunjukkan bahwa variabel independen, yaitu budaya organisasi $\left(X_{1}\right)$ dan komitmen organisasional $\left(\mathrm{X}_{2}\right)$ memiliki hubungan positif terhadap variabel dependen, yaitu kinerja karyawan $(Y)$ yang ditunjukkan dengan koefisien variabel yang bertanda positif. Selain itu, dari kedua nilai antara variabel bebas terdapat perbedaan dimana variabel komitmen organisasional $\left(\mathrm{X}_{2}\right)$ berpengaruh lebih besar dan signifikan terhadap peningkatan kinerja karyawan. Hal ini dapat dilihat dari koefisien masing-masing, dimana variabel komitmen organisasional $\left(X_{2}\right)$ 0,831 > variabel budaya organisasi (X1) 0,141.

\section{b. Pengujian Hipotesis}

Pengujian hipotesis yang dilakukan pada penelitian ini bertujuan untuk melihat bagaimana pengaruh variabel independen terhadap variabel dependen. Pengujian hipotesis ini terdiri atas koefisien determinasi, uji hipotesis secara parsial (uji t) dan uji hipotesis secara simultan (uji F). Adapun hasil dari pengujian tersebut dapat dijelaskan sebagai berikut:

1) Koefisien Determinasi $\left(R^{2}\right)$

Kekuatan pengaruh variabel bebas terhadap variabel terikat dapat diketahui dari besarnya nilai koefisien determinasi $\left(R^{2}\right)$ yang berada antara nol dan satu. Hasil nilai adjusted $R$ Square dari regresi digunakan untuk mengetahui besarnya struktur model yang dipengaruhi oleh variabel-variabel bebasnya. Hasil perhitungan koefisien determinasi berdasarkan olahan program SPSS 20 dapat dilihat pada tabel 4.4.2.1 berikut :

Tabel 4.4.2.1

Hasil Uji Koefisien Determinassi

\begin{tabular}{|l|r|r|r|r|}
\hline Model & $\mathbf{R}$ & R Square & $\begin{array}{c}\text { Adjusted R } \\
\text { Square }\end{array}$ & $\begin{array}{c}\text { Std. Error of } \\
\text { the Estimate }\end{array}$ \\
\hline 1 &, $716^{\mathrm{a}}$ &, 512 &, 495 & 1,980 \\
\hline
\end{tabular}

a. Dependent Variabel: $\mathrm{Y}$

Sumber :hasil olah data SPSS 20, 2015

Tabel 4.4.2.1 menunjukkan koefisien korelasi $(R)$ dan koefisien determinasi ( $R$ square). Dari tabel di atas diketahui bahwa nilai $R$ sebesar 0,716 atau sebesar $71,6 \%$ menunjukkan hubungan yang kuat karena mendekati nilai 1 atau dengan 
Jurnal Ekonomi Balance Fakultas Ekonomi Dan Bisnis

Volume 11 No 1 Tahun 2015

kata lain hal ini menunjukkan bahwa budaya organisasi dan komitmen organisasional memiliki hubungan yang kuat terhadap kinerja karyawan pada PT. Pelindo IV (Persero) Cab. Makassar. $R$ square menjelaskan seberapa besar variabel dependen yang dijelaskan oleh variabel $X$, dari hasil perhitungan diperoleh nilai $\mathrm{R}^{2}$ sebesar 0,512 atau $51,2 \%$. Adjusted $R$ Square merupakan nilai $\mathrm{R}^{2}$ yang disesuaikan dengan derajat bebasnya sehingga gambarannya lebih mendekati mutu penjajakan model, dari hasil perhitungan diperoleh nilai adjusted $R$ square sebesar 0,495 atau $49,5 \%$.

Hal ini berarti bahwa seluruh variabel bebas yakni budaya organisasi $\left(X_{1}\right)$, dan komitmen organisasional $\left(\mathrm{X}_{2}\right)$, mempunyai kontribusi secara bersama-sama sebesar 49,5\% terhadap variabel terikat yaitu kinerja karyawan (Y). Sedangkan sisanya yaitu sebesar $50,5 \%$ dipengaruhi oleh variabel lainnya yang tidak diteliti dalam penelitian ini. Kemudian standar error of the estimated adalah suatu ukuran banyaknya kesalahan model regresi dalam memprediksikan kinerja karyawan (Y). Dari hasil analisis regresi maka diperoleh nilai standar error of the estimated sebesar 1,980. Hal ini menunjukkan bahwa banyaknya kesalahan dalam memprediksi kinerja karyawan dapat ditentukan sebesar 1,980.

2) Uji Parsial (uji t)

Uji $\mathrm{t}$ dilakukan untuk mengetahui pengaruh masing-masing atau secara parsial variabel independen (budaya organisasi $\left(X_{1}\right)$ dan komitmen organisasional $\left(\mathrm{X}_{2}\right)$ ) terhadap variabel dependen (kinerja karyawan $(\mathrm{Y})$ ). Sementara itu secara parsial pengaruh dari kedua variabel independen tersebut dapat dilihat pada Tabel 4.4.2.2.

Tabel 4.4.2.2: Hasil uji parsia (Uji t)

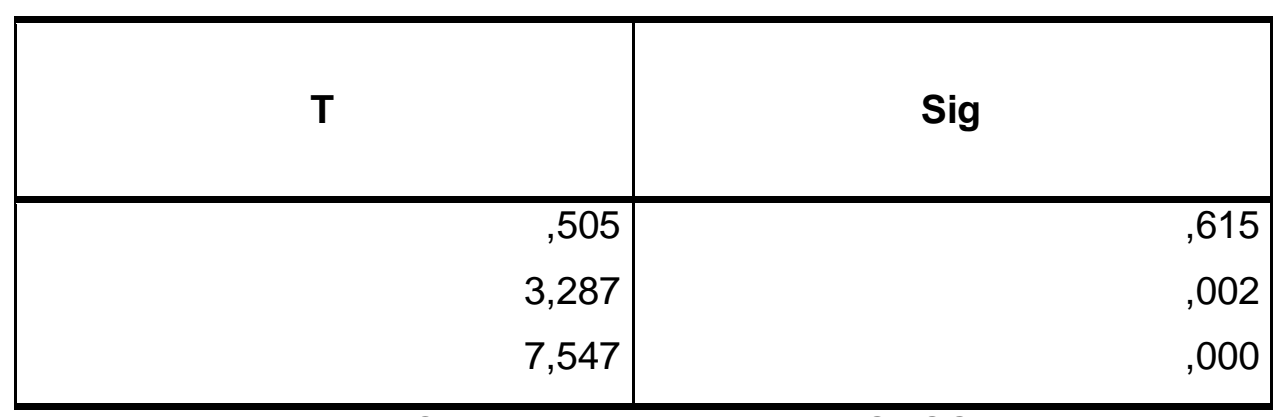

Dependent Variabel: Y Sumber :hasil olah data SPSS 20, 2015

Pengaruh dari masing-masing variabel budaya organisasi dan komitmen organisasional terhadap kinerja karyawan pada PT. Pelindo IV (Persero) Cab. Makassar, dapat dilihat dari arah tanda dan tingkat signifikan (probabilitas). Jika 
Jurnal Ekonomi Balance Fakultas Ekonomi Dan Bisnis

Volume 11 No 1 Tahun 2015

tingkat signifikansinya $<$ 0,05 maka dapat dikatakan bahwa variabel tersebut berpengaruh dan signifikan. Hal ini dapat diuraikan sebagai berikut:

\begin{tabular}{|rr|r|r|r|}
\hline Variabel & \multicolumn{1}{|c|}{ Uji t } & \multicolumn{1}{c|}{ T Hitung } & Hasil \\
\hline & X1 & 0,002 & 3,287 & signifikan \\
& X2 & 0,000 & 7,547 & signifikan \\
\hline
\end{tabular}

\section{1) Pengaruh Budaya Organisasi terhadap Kinerja Karyawan}

Dari hasil persamaan regresi diperoleh nilai koefisien regresi untuk budaya organisasi $\left(X_{1}\right)$ sebesar 0,141 , selain itu nilai signifikansi $0,002<0,05$, sehingga dapat dikatakan bahwa variabel budaya organisasi mempunyai pengaruh secara signifikan terhadap kinerja karyawan. Hal ini sejalan dengan pertanyaan dan pernyataan dalam kuesioner mengenai persepsi karyawan terhadap budaya organisasi (X1) (organisasi mempunyai kode etik yang memandu perilaku kita dan menjelaskan pada karyawan apa yang benar dan salah (X1.4) dapat mempengaruhi kinerjanya yang sesuai dengan pernyataan dalam kuesioner (saya mampu menyelesaikan semua pekerjaan dengan tepat dan sempurna (Y.1) Hal ini sesuai dengan teori yang dikemukakan oleh Robbins (2010:76) bahwa budaya organisasi telah diketengahkan sebagai nilai-nilai, prinsip-prinsip, tradisi dan cara-cara bekerja yang dianut bersama oleh para anggota organisasi dan mempengaruhi cara mereka bertindak, ketika karyawan memahami nilai-nilai yang ada dalam organisasinya, maka akan mempengaruhi bagaimana kinerjanya.

Hasil penelitian ini juga mendukung penelitian sebelumnya yang dilakukan oleh Pratiwi (2012:70) dalam penelitiannya menjelaskan bahwa budaya organisasi mempunyai pengaruh yang signifikan terhadap kinerja karyawan. Besarnya budaya organisasi berpengaruh $32 \%$ terhadap kinerja karyawan sedang $68 \%$ dipengaruhi oleh variabel lain. Hal ini berarti bahwa apabila budaya organisasi mengalami peningkatan, maka akan meningkatkan kinerja karyawan pula dan begitu pun sebaliknya, apabila budaya organisasi mengalami penurunan, maka kinerja karyawan pun akan mengalami penurunan. sehingga variabel budaya organisasi $\left(X_{1}\right)$ dalam penelitian ini dianggap sesuai dengan penelitian yang dilakukan oleh Pratiwi.

\section{2) Pengaruh Komitmen Organisasional terhadap Kinerja Karyawan}

Dari hasil perhitungan regresi, maka diperoleh koefisien regresi untuk komitmen organisasional $\left(X_{2}\right)$ sebesar 0,831 , selain itu nilai signifikansi sebesar 
Jurnal Ekonomi Balance Fakultas Ekonomi Dan Bisnis

Volume 11 No 1 Tahun 2015

$0,000<0,05$, sehingga dapat disimpulkan bahwa komitmen organisasional mempunyai pengaruh yang signifikan terhadap kinerja pegawai dan dapat diketahui pula bahwa variabel bebas yang paling berpengaruh terhadap kinerja karyawan adalah variabel komitmen organisasional $\left(\mathrm{X}_{2}\right)$ apabila dibandingkan dengan variabel lainnya. Variabel komitmen organisasional memiliki nilai signifikansi yang paling kecil dari variabel budaya organisasi $\left(\mathrm{X}_{1}\right)$ dengan nilai signifikansi sebesar 0,002.

Hal ini sejalan dengan pertanyaan dan pernyataan dalam kuesioner mengenai persepsi karyawan terhadap komitmen organisasional (X2) (saya merasa bahwa masalah dalam organisasi ini adalah masalah saya juga (X2.2)) dapat mempengaruhi kinerjanya yang sesuai dengan pernyataan dalam kuesioner (Y) (saya mampu mengambil inisiatif untuk menyelesaikan permasalahan dalam pekerjaan (Y.4)). Hal ini sesuai dengan teori yang dikemukakan oleh Robbins (2001:50) bahwa kualitas sumber daya manusia yang berpengaruh kuat terhadap kinerja organisasi adalah komitmen organisasi. Karyawan yang memiliki komitmen terhadap organisasi memiliki potensi untuk memperbaiki kinerja baik secara individual, kelompok maupun organisasi.

Hasil penelitian ini juga mendukung penelitian sebelumnya yang dilakukan oleh Sitty Yuwalliantin (2006) dalam penelitiannya menerangkan bahwa Komitmen terhadap organisasi artinya lebih dari sekedar keanggotaan formal, karena meliputi sikap menyukai organisasi dan kesediaan untuk mengusahakan tingkat upaya yang tinggi bagi kepentingan organisasi demi pencapaian tujuan. Jadi seseorang yang memiliki komitmen tinggi akan memiliki identifikasi dengan organisasi, terlibat sungguh-sungguh dalam pekerjaan dan ada loyalitas serta afeksi positif terhadap organisasi. Dimana komitmen organisasi memberi pengaruh positif dan signifikan terhadap kinerja, sehingga dapat dikatakan bahwa variabel komitmen organisasional $\left(X_{2}\right)$ dalam penelitian ini sejalan dengan penelitian yang dilakukan oleh Sitty Yuwalliantin.

\section{PENUTUP}

\section{Simpulan}

1. Berdasarkan hasil pengujian dengan menggunakan model regresi linear berganda, maka dapat disimpulkan bahwa variabel budaya organisasi $\left(\mathrm{X}_{1}\right)$ dan komitmen organisasional $\left(\mathrm{X}_{2}\right)$ menampakkan hasil yang positif dan signifikan terhadap peningkatan kinerja karyawan pada PT. Pelabuhan 
Jurnal Ekonomi Balance Fakultas Ekonomi Dan Bisnis

Volume 11 No 1 Tahun 2015

Indonesia IV (Persero) Cab. Makassar. Dengan demikian hipotesis pertama yang mengatakan bahwa budaya organisasi dan komitmen organisasional memberi pengaruh yang signifikan dalam membangun kinerja kinerja karyawan pada PT. Pelabuhan Indonesia IV (Persero) Cab. Makassar dapat diterima.

2. Berdasarkan hasil pengujian regresi, maka dapat diketahui bahwa variabel yang paling besar pengaruhnya dalam membangun kinerja karyawan adalah variabel komitmen organisasional $\left(X_{2}\right)$. Dari apa yang ditunjukkan oleh model analisis tersebut, dapat disimpulkan bahwa hipotesis kedua yang menyatakan bahwa komitmen organisasional adalah variabel yang dominan berpengaruh dalam membangun kinerja karyawan pada PT. Pelabuhan Indonesia IV (Persero) Cab. Makassar, dapat diterima.

\section{Saran}

1. Disarankan pula untuk menciptakan dan mengoptimalkan budaya organisasi yang kondusif, terutama pada aspek prioritas masukan informasi dari pelanggan, sebab dengan pengoptimalan budaya organisasi yang kondusif dan efektif akan dapat meningkatkan kinerja karyawan pada PT. Pelindo IV (Persero) Cab. Makassar. Karena butir tersebut memiliki nilai skor terendah dalam analisis deskriptif.

2. Disarankan pula kepada pimpinan untuk dapat lebih memperhatikan dan meningkatkan serta mempertahankan komitmen para pegawai dalam lingkup PT. Pelindo IV (Persero) Cab. Makassar, terutama yang berkaitan pada aspek keinginan karyawan untuk bertahan dan menghabiskan karirnya pada perusahaan, sebab pernyataan ini merupakan pernyataan yang memiliki nilai terendah pada analisis deskriptif. 
Jurnal Ekonomi Balance Fakultas Ekonomi Dan Bisnis

Volume 11 No 1 Tahun 2015

\section{DAFTAR PUSTAKA}

Arikunto. 1996. Prosedur Penelitian, Suatu Pendekatan Praktis. Jakarta: Rineka Cipta

Christy, Hasna. 2004. Hubungan antara budaya organisasi dengan komitmen organisasi pada perawat rumah sakit panti wilasa citarum semarang.- Jurnal

Denison dan Mishra. 2000. Organizational culture and organizational effectiveness: a theory and some preliminary empirical evidence. School of business administration. University of Michigan.

Ghozali, Imam. 2011. "Aplikasi Analisis Multivriate dengan Program SPSS" , Semarang: Badan Penerbit Universitas Diponegoro.

Ghozali, Imam. 2009. Ekonometrika Teori, konsep dan aplikasi dengan program SPSS. Semarang : Badan Penerbit Universitas Diponegoro

Ilyas, Yaslis 2002. Kinerja; teori, penilaian, dan penelitian. Depok: Pusat Kajian Ekonomi Kesehatan FKMUI.

Istijanto. 2005. Management Communication. Jakarta: PT. Gramedia Pustaka Utama

Luthans, Fred 2008. Organizational behavior.United States: McGraw-Hill.

Luthans, Fred and Richard Hodgetts, 2003. International management; culture, strategy, and behavior. United States: McGraw-Hill.

Masri, Singarimbun. 2006. Metode Penelitian Survei. Jakarta: LP3S

Mathis, Jackson. 2009. Human resource management. Jakarta: Salemba Empat

Mudrajad, Kuncoro, 2003. Metode Riset untuk Bisnis dan Ekonomi; Jakarta: Erlangga

Munandar, Ashar. 2001. Psikologi Industri dan Organisasi. Jakarta: Penerbit Universitas Indonesia.

Pratiwi, Riska. 2012. Pengaruh budaya organisasi terhadap kinerja pegawai pada kantor pelayanan kekayaan negara dan lelang Makasar, program 
Jurnal Ekonomi Balance Fakultas Ekonomi Dan Bisnis

Volume 11 No 1 Tahun 2015

studi manajemen, Fakultas Ekonomi dan Bisnis Universitas Hasanudin: Makasar.

Robbins, stephen, dan Mary Coulter. 2001. Manajemen. Jakarta: Erlangga

Robbins, Stephen P, dan Timothy. 2008. Perilaku Organisasi. Ed.12. Jakarta: Salemba Empat.

Setiawan, Andy. 2009. Pengaruh Karaktteristik Individu dan Faktor-faktor Pekerjaan Terhadap Motivasi (Studi pada karyawan CV. Bintang Timur Semarang). Jurnal MSDM. Hal. 1-8.

Stephen, Robins, 2003. Perilaku organisasi. Gramedia: PT Indeks.

Steve. 2002. Organizational psychology. United States of America: Library of Congress Cataloging.

Sugiyono. 2009. Metode Penelitian Kuantitatif, Kualitatif dan $R \& D$. Bandung: Alfabeta

Sugiyono. 2011. Statistika Untuk Penelitian. Bandung: Alfabeta

Valentine, Godkin, Lucero. 2010. Ethical context, organizational commitment, and person-organization fit. Journal of business ethics. Vol. 41. No. 4. Springer.

Wirawan. 2009. Manajemen Kinerja. Jakarta : Gramedia Pustaka

Wibowo. 2007. Menejemen kinerja. Jakarta: PT RajaGrafindo Persada.

Wirjana, Bernandine 2007. Mencapai manajemen berkualitas; organisasi, kinerja, program. Yogyakarta: Penerbit Andi Offset.

Yamin, Sofyan dan Heri Kurniawan, 2009. "SPSS Complete", Jakarta: Salemba Infotek. 